\title{
純 $\mathrm{Ti} /$ 純 $\mathrm{Al}$ 摩擦圧接継手境界部の応力・ひずみ，音速 および硬さ分布に関する検討*
}

\author{
冨士 明良**, 粉川 博之***, 金 裕哲****

\begin{abstract}
A Study of Stress-strain, Acoustic Wavevelocity and Hardness Distributions Across Joint Interface of Pure Ti/Pure Al Friction Weld Joint*
\end{abstract}

\author{
by Akiyoshi FUJI**, Hiroyuki KOKAWA*** and You-Chul KIM****
}

\begin{abstract}
In order to clarify the stress/strain distribution across the joint interface of friction weld between pure titanium (Ti)/pure aluminium ( $\mathrm{Al})$, the characteristics of the joint interface have been investigated in view of ultrasonic leaky surface acoustic (Rayleigh) wave velocity $\left(V_{R}\right)$ and hardness distributions across it. Especially, one of the first efforts is focused on whether a mechanical scanning acoustic microscope (SAM) can be utilized to measure the $V_{R}$ distribution across the interface or not. The effect of tensile/compressive strains on $V_{R}$ of $T i$ and $A l$ substrates, the relation of crystal direction versus $V_{R}$ for single crystal pure $\mathrm{Al}$ substrate, and $\mathrm{V}_{\mathrm{R}}$ distribution across as-welded and post-weld heat-treated $\mathrm{Ti} / \mathrm{Al}$ friction joints have been investigated by using a SAM.

As for Ti and $A l$ substrates, all direction (isotropic) $V_{R}\left(A V_{R}\right)$ decreased when the applied tensile strain increased in elastic deformation region, however, they increased as increasing applied strain in plastic one. Compressive strain slightly affected the change of $A V_{R}$ versus in both elastic and plastic deformation regions. Uni direction (anisotropic) $V_{R}\left(U V_{R}\right.$ ) increased as increasing tensile and compressive strains for Ti substrate. While $U V_{R}$ of $A l$ substrate decreased with increasing of tensile strain, it increased for compressive strain. There was clear relation between $U V_{R}$ and crystal direction of single crystal pure $\mathrm{AI}$ substrate, and the highest $\mathrm{UV}_{\mathrm{R}}$ was obtained at the direction parallel to the most close-packed crystal direction of $f c c$ metal ([101]).

In case of as-welded $T i / A l$ friction joint, the scatter of $A V_{R}$ distribution was relatively high overall the measured region, and $A V_{R}$ of $A l$ substrates adjacent to the joint interface was relatively high. It was thought that this high $A V_{R}$ was resulted from high plastic strain generated during friction weld operation. The scatter of $A V_{R}$ distribution was reduced and the high $A V_{R}$ was not observed when the joint was post-weld heat-treated. While axial direction $U V_{R}$ of Al substrate adjacent to the joint interface was extremely high in as-welded condition, that of radial direction was not high. Those of Ti side were not high in as-welded joint. The $V_{R}$ distributions were relatively similar characteristics to hardness and calculated stress/strain distributions.
\end{abstract}

Key Words : friction welding, aluminium, titanium, stress, strain, Rayleigh wave, scanning acoustic microscope, acoustic wave velocity, sound velocity

\section{1. 緒言}

異種材料の接合継手（異材継手）は，各種産業機器の部 材に数多〈用いられており，現代工業に扔いて必要不可欠 なものとなっている．著者らは過去溶融溶接法では異種金 属材料との接合が困難であるチタニウム (Ti) 系材料に着 目し，固相接合法である摩擦圧接法を用いて SUS304L ス テンレス鋼あるいはアルミニウム（Al）合金との接合を行 い, 継手の評価を行ってきた ${ }^{1-5)}$. さらに，異材継手の機械

*原稿受付 平成11年11月15日 平成 9 年度秋季全国大会で発表

**正員 北見工業大学 Member, Kitami Institute of Technology

***正 員 東北大学 Member, Tohoku University

****正 員 大阪大学接合科学研究所 Member, Joining and Welding Resarch Institute, Osaka University
的特性を左右する重要な因子の一つである接合部近傍に生 じる応力・塑性ひずみに関連した報告を行っている6,7)。 の応力・Uずみの非破壊的な評価法としてX線応力測定法 があるが, 接合界面をはさむ微小な領域の測定を行なうこ とは実用上困難となっている。ところで，溶接継手の主要 な非破壊検查法の一つに超音波を用いた検查法があるが, この中で超音波顕微鏡（acoustic microscope）を用いる方 法はここ10数年着目されている技術である。すなわち，音 波は伝播する媒質の硬さおよび密度等の物性值亚びに応 力・Uずみ状態によって伝播速度が変化する特性を有して いるため8), 超音波の表面弾性波を測定することにより接 合境界部における応力・Uずみを推定できる可能性を有す る. とくに, $10 \mu \mathrm{m}$ 程度の高分解能で材料表面下の観察が 可能である機械走查型超音波顕微鏡 (scanning acoustic microscope；以下, SAM という) が注目されている9-11). SAM は弾性率の分析モードを備えており，受信信号電圧 
曲線 $(V(z)$ 曲線) 法を用いることにより，試料表層を伝播 する弾性表面波の伝播速度（以下，音速という）を測定で きる.現在まで, SAM を用いた材料の加工変質層の厚さ測 定 $^{12,13)}$, 材料中の応力・Uずみの推定や塑性変形域検 出 ${ }^{14-16)}$, 材料の弾性定数の測定 ${ }^{17)}$, 材料劣化の評価 ${ }^{18)}, \mathrm{Al}$ 合金の溶接凝固組織の検討 ${ }^{19)}$, 高分子材料の材料評価や欠 陷の模出 ${ }^{20-23)}$, 超音波の伝ば特性に及ぼ子周波数の依存性 の検討 ${ }^{24)}$ 等が行われている.ところで, 異材継手の強度に 大きな影響を与える境界部に生じる残留応力・ひずみを SAMにより求めた音速分布から解析や推定を行った研究 は少なく,金属/七ラミックスの接合界面におけるセうミッ クス側の音速分布から推定した残留応力などについては報 告されているものの ${ }^{25,26)}$, 異種金属境界部の応力・ひずみに 関する報告はほとんど見当たらない.

本研究では，異種金属として Ti と $\mathrm{Al}$ を取り上げ，摩擦 継手の圧接面を横切る数 $\mathrm{mm}$ の微小領域における全方位 および方向性を有する音速分布を SAM を用いて測定し， 音速の変化から応力・ひずみの推定が可能かどうか明らか にすることを目的としている，本報告では，その基礎デ一 タとして， $\mathrm{Ti}$ および $\mathrm{Al}$ 母材の引張および圧縮ひずみと音 速との関係，並びに $\mathrm{Al}$ 単結晶の結晶方位と音速の関係を 求めた.また，接合したまま並びに後熱処理を施した $\mathrm{Ti} / \mathrm{Al}$ 摩擦圧接継手の圧接面をはさむ微小領域の音速と硬さを測 定し, 有限要素法による熱弾塑性解析で求めた残留応力・ ひずみとの関係について比較検討を行った。

\section{2. 実 験 方 法}

\section{1 供試材料および音速測定用試験片}

本研究で使用した材料は, 外径 $16 \mathrm{~mm}$ の市販の工業用純 Ti（JIS TB-35H） およU゙工業用純 Al（JIS A1100）であ る. 純 $\mathrm{Ti} の 0.2 \%$ 耐力は $360 \mathrm{MPa}$, 引張強さは $460 \mathrm{MPa}$, 伸びは $31 \%$, 純 $\mathrm{Al}$ のそれらは $44 \mathrm{MPa}, 86 \mathrm{MPa}, 47 \%$ あ る.

$\mathrm{Al}$ 抢よびTi 母材の音速测定用試験片は以下の方法で作 製した.引張試験片は, Fig. 1 (a)に示すように平行部の幅 5 $\mathrm{mm}$, 厚さ $2 \mathrm{~mm}$, 長さ約 $25 \mathrm{~mm}$ に加工.し, 観察面をエメ リー紙による\#1500まで研磨を行った後, ダイヤモンドペーー ストを用いてバフ研磨を行った，圧縮試験片はFig. 1(b)に 示すように直径 $12 \mathrm{~mm}$, 長さ $72 \mathrm{~mm}$ の円柱状であり, 音速 測定部として幅約 $7 \mathrm{~mm} \times$ 長さ約 $32 \mathrm{~mm}$ の平面をフライ 又盤を用いて加工した。 その後, 引張試験片と同様に観察 面の研磨を行った，材料の製造時，並びに試験片加工時に 生しる応力・ひずみを除去するため, Ti は $873 \mathrm{~K}-3.6 \mathrm{ks}$, $\mathrm{Al}$ は623 K-3.6 ks の熱処理を真空炉中で施し,ひずみを極 力除去した状態で実験に供した。引張試験片は反対の平面 に，圧縮試験片は反対の曲面にひずみゲージを貼り付けて 負荷ひずみを求めた。両母材と毛，引張および圧縮ひずみ

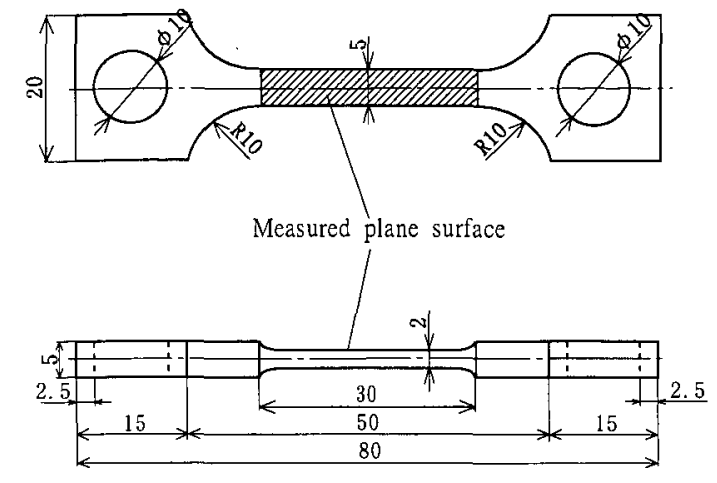

(a) Tensile test specimen

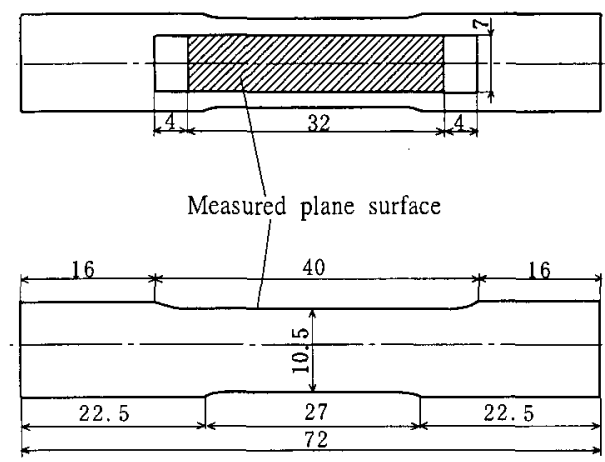

(b) Compressive test specimen

Fig. 1 Dimension and configuration of tensile and compressive test specimens for $A V_{R}$ and $U V_{R}$ measurement of (a) tensile and (b) compressive tests.

$\uparrow \mathrm{Y}\left(0^{\circ}\right)$;

crstal direction (C.D.) ;

$[0.934,0.118,0.336]$

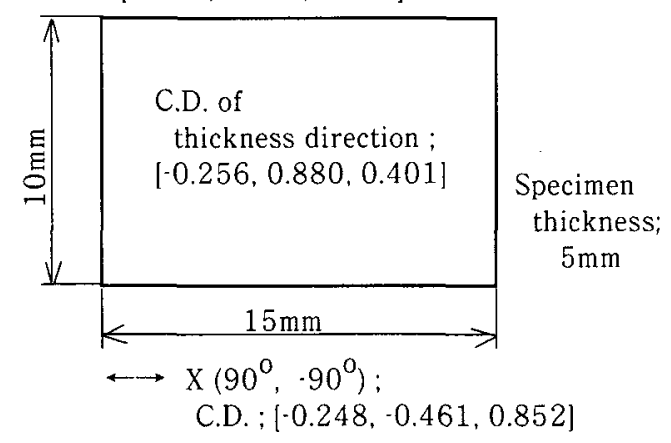

Fig. 2 Crystal direction of single crystal pure $\mathrm{Al}$.

は $5 \%$ \%で負荷し，音速を測定した。

結晶方位と音速の関係を求めるために使用した $\mathrm{Al}$ 単結 晶は，ブリッジマン法による結晶成長装置を用い, 99.996 mass\%の $\mathrm{Al}$ 素材を $\mathrm{Ar}$ 雾囲気中で凝固成長させて作製し た、試料サイズは長さ $15 \mathrm{~mm}$, 幅 $10 \mathrm{~mm}$, 厚さ $5 \mathrm{~mm}$ であ る。凝固後，試験片表面をエメリ一紙とバフ研磨後， $20 \%$ 過塩素酸 $+80 \%$ エ 解研磨を行った. 試料の結晶方位を Fig. 2 に示す. 


\section{$2.2 \mathrm{Ti} / \mathrm{Al}$ 摩擦圧接継手の作製方法}

$\mathrm{Al}$ の変形が Tiに比較して大きいので, Tiについては旋 盤を用いて接合部の外径を $12 \mathrm{~mm}, \mathrm{Al}$ については $16 \mathrm{~mm}$ のままとして，接合端面をバフ研磨して仕上げた。材料の 製造過程, 並びに旋盤加工に起因した応力・Uずみの存在 が考之られたため, 接合に先立ち Ti は $873 \mathrm{~K}-3.6 \mathrm{k}, \mathrm{Al}$ は $623 \mathrm{~K}-3.6 \mathrm{ks} の$ 熱処理を真空炉中で施した状態で接合を 行った，接合にはブレーキ式摩擦圧接機を用いた，圧接条 件は, 過去の研究で接合後の継手引張試験において, $\mathrm{Al}$ 母 材で破断する（圧接面破断を生じない）継手を得ることが できる回転数 $25 \mathrm{~s}^{-1}$, 摩擦圧力 $50 \mathrm{MPa}$, 摩擦時間 $2 \mathrm{~s}$, アプ セット圧力 $50 \mathrm{MPa} ， ア フ ゚ セ ッ ト$ 時間 $6 \mathrm{~s}$ を用いた。継手境 界部の音速および硬さ測定用試験片は以下の方法で作製し た. 旋盤を用いて継手を外径 $12 \mathrm{~mm}$ に旋削後，压接面をは さんで全長 $20 \mathrm{~mm}$ に切断した，さらに中心軸を含む断面で 切断し，観察面をダイヤモンドペーストを用いてバフ研磨 した。接合したままの状態 (AW) に加之，Alの再結晶温 度に近い $573 \mathrm{~K}-3.6 \mathrm{ks}$ ， $\mathrm{Ti}$ の再結晶温度および $\mathrm{Al}$ の融点 に近くかつ $\mathrm{Al}$ の力学的強度が 0 に近いと考之られる $873 \mathrm{k}$ $-3.6 \mathrm{ks} の 2$ 種類の後熱処理を行った. 以下，これらの継手 をそれぞれ $573 \mathrm{~K}$ 継手，および873 K 継手とよぶ。な㧍，試 験片を軸方向に平行に切断することで, 継手の周方向の残 留応力と弾性ひずみは完全に，また半径方向および軸方向 のそれらは一部開放されるものと推定される。しかし，各 方向の塑性ひずみは残存するものと推定されるので, 本研 究ではこれらの状態において音速並じに硬さを測定し，応 カ・Uずみ分布の検討を行った。

\section{3 音速測定方法}

本研究では，日立建機株式会社製機械走查式反射型超音 波顕微鏡 HSAM200を使用した。装置の構成をFig. 3 に示 す. 使用した音響レンズの周波数は $200 \mathrm{MHz}$ であるが, Ti

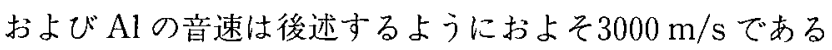
ので, 波長は約 $15 \mu \mathrm{m}$ となる.また，梁さ力向の分解能(梁 度分解能）を $\Delta \mathrm{L}$, 表面に沿j方向の分解能（方位分解能） を $\Delta \mathrm{r}$ とすると，それぞれ(1)および(2)式で求まる10).

$$
\begin{aligned}
& \Delta \mathrm{L}=2 \times \lambda \times \mathrm{F}^{2} \\
& \Delta \mathrm{r}=\lambda \times \mathrm{F}
\end{aligned}
$$

これより， $\Delta \mathrm{L}$ は $15 \mu \mathrm{m}, \Delta \mathrm{r}$ は約 $11 \mu \mathrm{m}$ となり，いずれも 波長に近い值となる。.ところで，金属材料を加工した場合 には通常数 $\mu \mathrm{m}$ の変質層（加工層）が生じるとされている が13), 本報告に招ける試料表面は, 最終的にはダイヤモンド ペーストを用いてバフ研磨を行なっているので，音速測定 への変質層の影響はほとんど無視できるものと考えられ る.

測定位置は, Fig. 4 に示寸ように軸心部，軸心部より 3 $\mathrm{mm}$ 外周部に向かった位置 (1/2 R 部), および外表面から $0.5 \mathrm{~mm}$ 軸心に入った位置 (外周部)の 3 力所とした。この

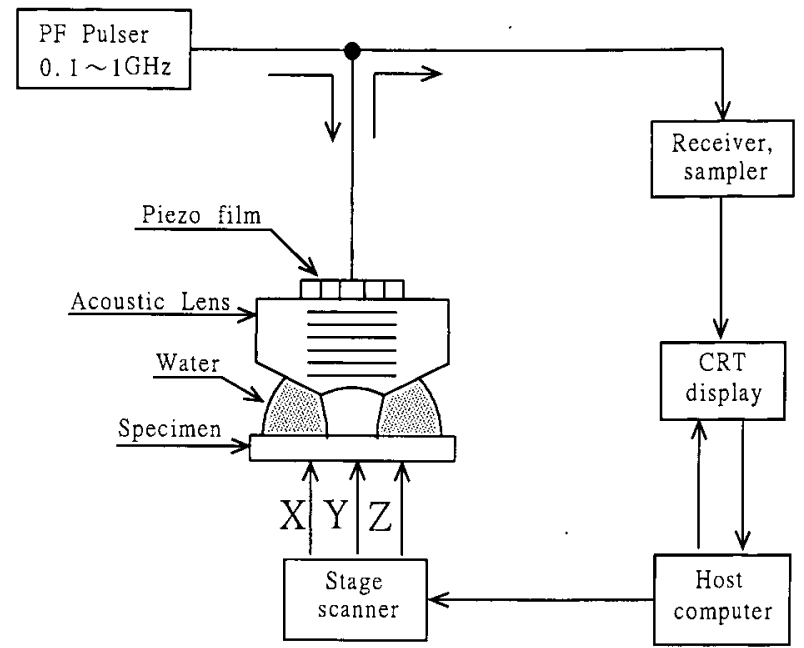

Fig. 3 Schematic diagram of SAM used for experiment.

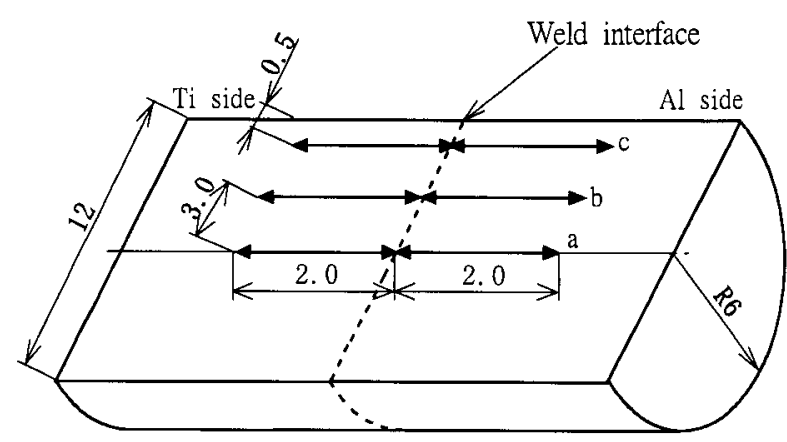

Measuring line; $a$ : center, $b: 1 / 2 R, c:$ periphery [unit:mm ]

Fig. 4 Measured location for $V_{R}$ and hardness test.

3 力所において, 圧接面より両母材側にそれぞれ $2 \mathrm{~mm}, つ$ まり約 $4 \mathrm{~mm} の$ 範囲を80分割し，音響レンズを振動させる ことで幅50 $\mu \mathrm{m}$ の範囲の平均の音速を求めた. データは示 していないが, 本研究における $\mathrm{Ti}$ および $\mathrm{Al}$ の結晶粒は直 径約 $15 \mu \mathrm{m}$ 程度であるので, 測定に当たっては複数個の結 晶粒の音速が求められることになる。測定時, 音響レンズ と材料の間のカップラントには水を用いた。 また, 音速測 定は室温293〜303 K で行い, 測定後温度補正を行った.

SAM では通常，点集束型レンズで超音波の弾性表面波 の音速測定を行い, これが全方位音速 (以下, $A V_{\mathrm{R}}$ という) となる。しかし，点集束型レンズでは，音響レンズの形状 が中心軸に対して回転対称であるので, 360 度の全方向に伝 播する表面波の平均的な音速しか求められず，材料の音響 異方性の計測はできない。しかし，音響レンズの表面にス リットを装着することにより，焦点面上に方向性を持った 超音波ビームが形成され，単一方向に伝播する弾性表面波 の測定が可能となる.さらにこのレンズを回転させるこ とにより試料の音響異方性が求められると同時に，応力の 方向性を推定できる可能性を有する。そこで本研究では， 


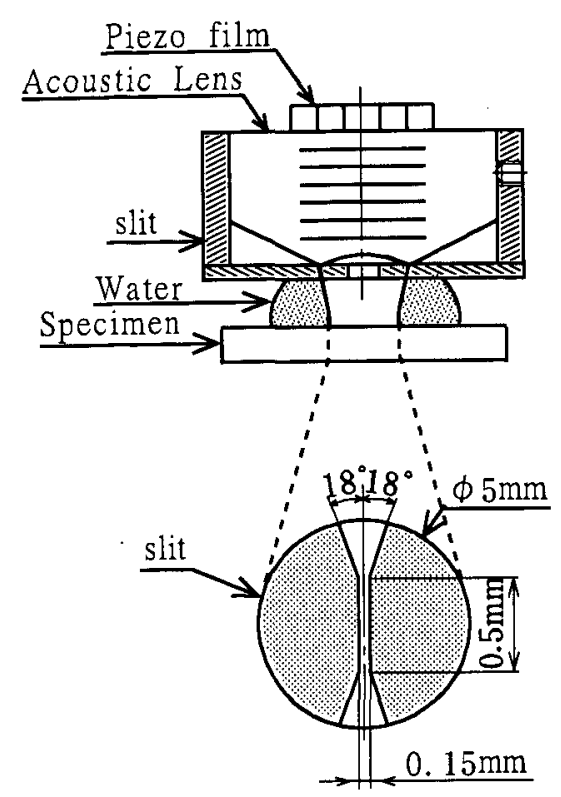

Fig. 5 Dimension and configuration of slit to measure $\mathrm{UV}_{\mathrm{R}}$.

Fig. 5 に示すようなスリットを装着した音響レンズを用 い, Ti 拉よび $\mathrm{Al}$ 母材に引張捛よび圧縮応力を負荷し, 力向 性を有する音速 $\left(\mathrm{UV}_{\mathrm{R}}\right)$ の変化を求めた。また, $\mathrm{Ti} / \mathrm{Al}$ 継 手については圧接面を横切る位置で $\mathrm{UV}_{\mathrm{R}}$ を求め, 応力・U ずみの方向性を解明した。なお，Fig. 5 に示すように，ス リットの間隔は $0.15 \mathrm{~mm}$, 長さ $0.5 \mathrm{~mm}$, 半開口角は理論値 と良く一致する18度とした ${ }^{20)}$.

純 $\mathrm{Al}$ 単結晶試験片の結晶方位と音速の関係を求めるた めに, Fig. 2 に示した試料の中央部において試料を回転さ せて音速測定を行った.

ところで，同一材料であっても音速は種々の因子によっ て影響を受けるので, 本研究では音速の絶対值ではなく, $\mathrm{Ti}$ および $\mathrm{Al}$ 母材原質部あるいは引張および圧縮試験につ いては負荷ひずみ $0 \%$ 音速 $\left(\mathrm{VR}_{0}\right)$ を基準とし，それらの 值と各音速との差から変化の割合 $\mathrm{VR}_{\mathrm{d}}$ を(3)式によって求 め, 考察を行った.

$$
\mathrm{VR}_{\mathrm{d}}=\left\{\left(\text { 測定值 }-\mathrm{VR}_{0}\right) / \mathrm{VR}_{0}\right\} \times 100[\%]
$$

\section{$2.4 \mathrm{Ti} / \mathrm{Al}$ 継手接合界面を横切る硬さの測定}

硬さ測定にはビッカース微小硬さ計を用いた。测定位置 は Fig. 4 に示す軸心部，1/2 R 部㧍よび外周部の 3 力所と し，圧接面より両母材にそれぞれ $2 \mathrm{~mm}$ の位置までの範囲 の測定を行った。測定荷重は $\mathrm{Ti}$ 側は $9.81 \mathrm{~N}(1 \mathrm{kgf}), \mathrm{Al}$ 側 は0.49 N (50 gf) とした。

\section{3. 実 験 結 果}

\section{$3.1 \mathrm{Ti}$ および $\mathrm{Al}$ 母材の音速に及ほすす引張および圧縮 ひずみの影響}

$\mathrm{Al}$ 母材並びに Ti 母材に引張応力を負荷し，ひずみと全 方位音速 $\left(\mathrm{AV}_{\mathrm{R}}\right)$ との関係を求めた結果を Fig. $6(\mathrm{a})$ に示寸。 ひずみ $0 \%$ (無負荷)における $\mathrm{Ti} の \mathrm{AV}_{\mathrm{R}}$ は約 $2970 \mathrm{~m} / \mathrm{s}$, $\mathrm{Al}$ のそれは約 $3040 \mathrm{~m} / \mathrm{s}$ であった。負荷Uずみが約 $0.2 \%$ に 達するまで,すなわちほぼ弹性領域と考えられる範围では, 而材料の $\mathrm{AV}_{\mathrm{R}}$ はUずみに比較して低下し，その值は最大 約 $-0.6 \%(-18 \mathrm{~m} / \mathrm{s})$ になっている，その後約 $2 \%$ はすみ
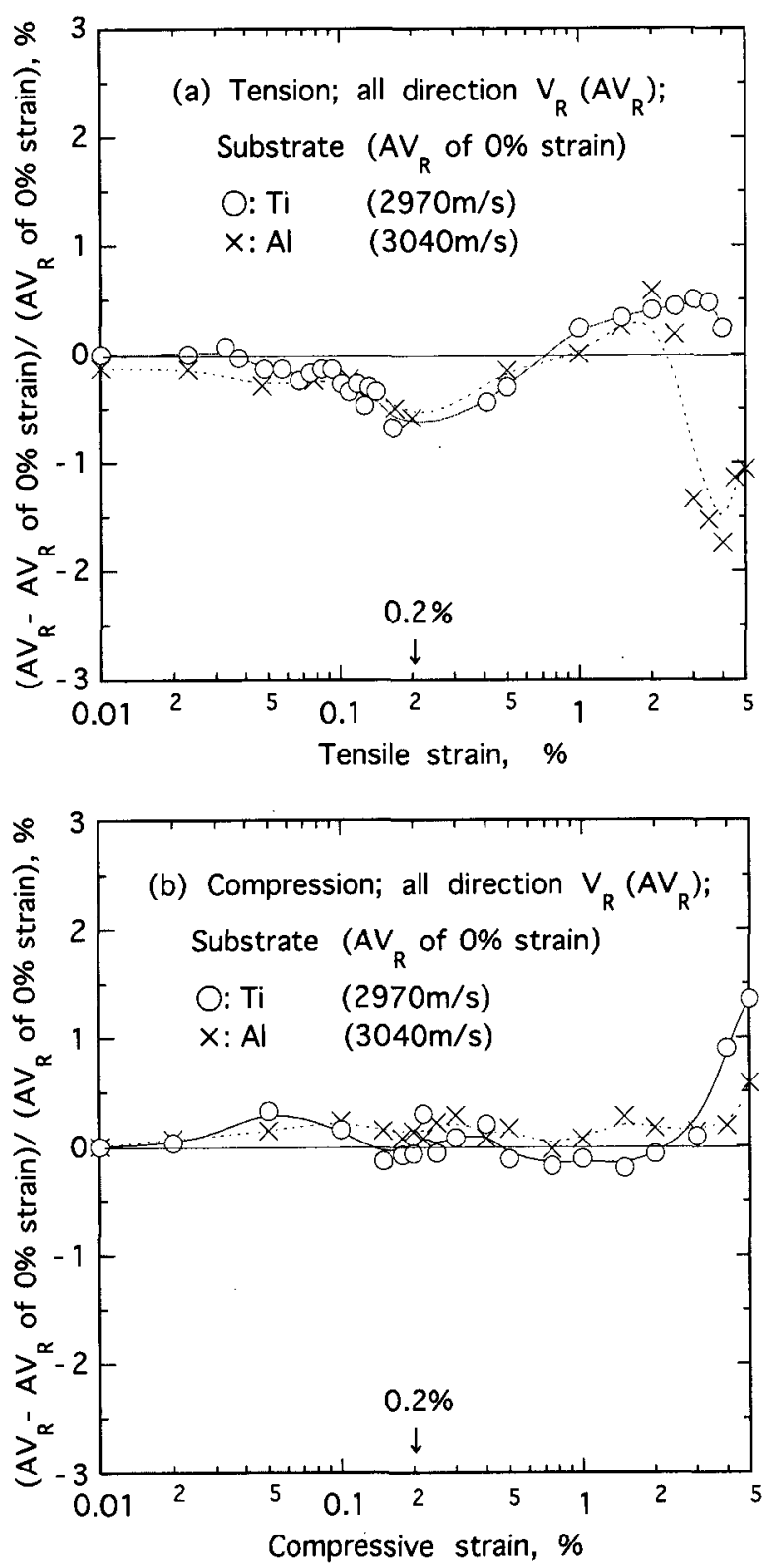

Fig. 6 Relation between applied strain and deviation of $\mathrm{AV}_{\mathrm{R}}$ of $\mathrm{Ti}$ and $\mathrm{Al}$ substrates of (a) tensile and (b) compressive strain. 
までは $\mathrm{AV}_{\mathrm{R}}$ は増加に転じている，さらにUずみが増加す ると， $\mathrm{Ti} の \mathrm{AV}_{\mathrm{R}}$ は約 $0.6 \%(18 \mathrm{~m} / \mathrm{s})$ まで上昇しているが， 一方，Al では急激に低下し，最小值は約 $-1.8 \%(-55 \mathrm{~m} /$ s）になっている。玨縮の負荷ひずみと $\mathrm{AV}_{\mathrm{R}}$ との関係を求 めた結果をFig.6(b)に示す。約 $3 \%$ みずみまでは，Tiの $\mathrm{AV}_{\mathrm{R}}$ の変化は最大約 $+0.6 \%(+18 \mathrm{~m} / \mathrm{s})$ であり, 一方, $\mathrm{Al}$ のそれは約 $+0.2 〜+0.3 \%(+6 〜+9 \mathrm{~m} / \mathrm{s})$ である。つま ク，両材料ともUずみの増加に対する音速の大きな変化は 認められない.Ti 拈よび $\mathrm{Al}$ とも, 負荷Uずみが約 $3 \%$ を超 えると $\mathrm{AV}_{\mathrm{R}}$ の変化は大きくなっている，ところで，多結晶 金属材料の SAM に上る音速のばらつきは，とくに結晶系 の複雑な $\mathrm{Ti} て ゙ は \pm 20 \mathrm{~m} / \mathrm{s}(1.5 \%)$ 程度の音速のばらつき
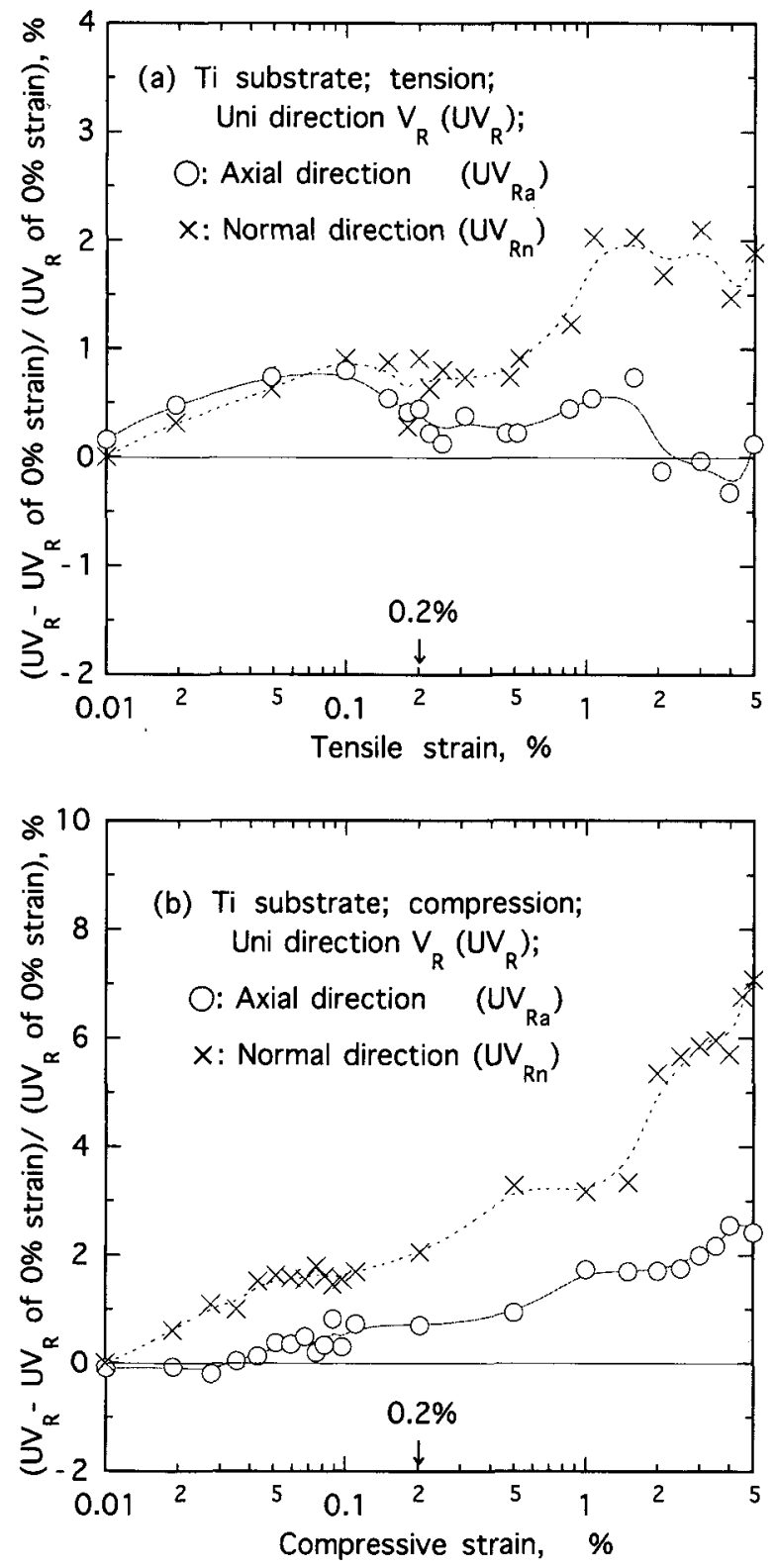

Fig. 7 Relation between applied strain and deviation of $\mathrm{UV}_{\mathrm{R}}$ of $\mathrm{Ti}$ substrate of (a) tensile and (b) compressive strain.
があるとの一般的な意見もある。このことから，Fig. 6(a)を 始めたとした結果の測定精度が問題となるが，Uずみの増 加に对寸る音速の変化の傾向は, ある程度信頼度の高いも のと考えられる。

$\mathrm{Ti}$ 母材に引張応力を負荷し，スリットを有する音響レン ズを用いて求めた負荷方向（軸方向）に伝播する音速 $\left(U V_{\mathrm{Ra}}\right)$ 並びに負荷に垂直な力向の音速 $\left(U_{\mathrm{Rn}}\right)$ を測定し た結果を Fig. 7 (a)に示す. $A V_{\mathrm{R}}$ と異なり，ひずみの増加と ともに両方向の音速とも增加している.引張ひずみが約 $0.1 \%$ をで増加すると $\mathrm{UV}_{\mathrm{Ra}}$ は約 $0.8 \%(24 \mathrm{~m} / \mathrm{s})$ 増加し， その後音速は低下して約 $0.3 \sim 0.5 \%(9 \sim 15 \mathrm{~m} / \mathrm{s})$ 前後で 推移している。一方, $\mathrm{UV}_{\mathrm{Rn}}$ はUずみ約 $0.1 \%$ ま゙ $\mathrm{UV}_{\mathrm{Ra}}$ と
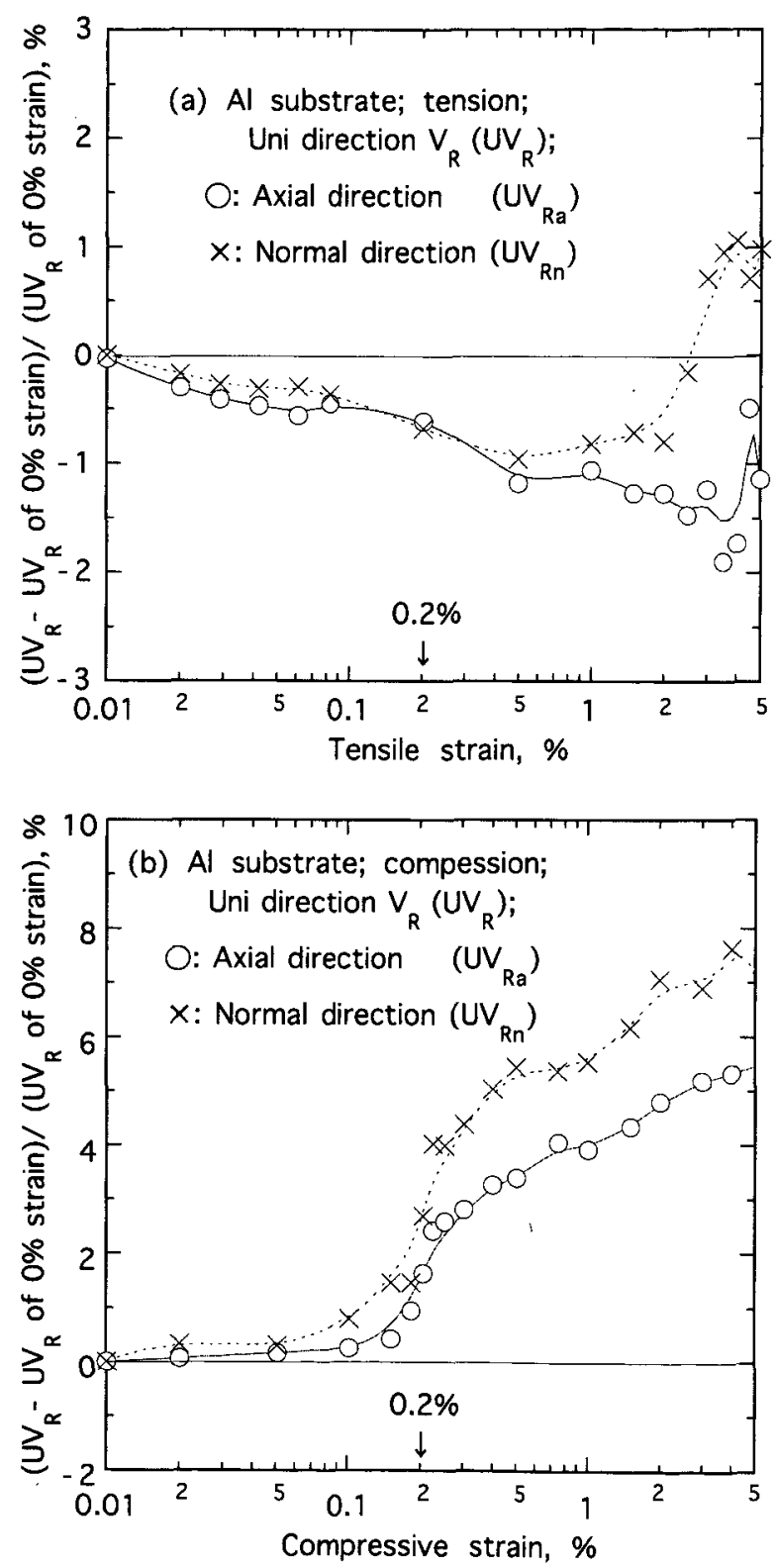

Fig. 8 Relation between applied strain and deviation of $\mathrm{UV}_{\mathrm{R}}$ of $\mathrm{Al}$ substrate of (a) tensile and (b) compressive strain. 
ほぼ同じ変化を示している。ひずみが約 $1 \%$ \%ではほぼ一 定值を示すが (約 $0.8 \%$ )，約 $1 \%$ 以上で音速は急激に増加 し，その值は約 $2 \%(+60 \mathrm{~m} / \mathrm{s})$ 近くまで上昇している. 圧縮応力を負荷したときの結果を Fig. 7(b)に示すが, 実験 の範囲に扔いて UV $\mathrm{UV}_{\mathrm{Ra}} よ り も \mathrm{UV}_{\mathrm{Rn}}$ の方が㧈よそ約 0.5 4\% (15〜20 m/s) 大きい. 約 $2 \%$ Uずみまではひず みの增加とともに雨音速は增加し， $\mathrm{U}_{\mathrm{VRa}}$ は約 $+1.5 \%(+45$ $\mathrm{m} / \mathrm{s}), U_{\mathrm{VRn}}$ は約 $+3.2 \%(+95 \mathrm{~m} / \mathrm{s})$ になっている、Uず みが $2 \%$ 以上になると, $\mathrm{U}_{\mathrm{VRa}}$ の増加は少ないものの, $\mathrm{U}_{\mathrm{VRn}}$ は急激に増加し最大約 $+7 \%(+210 \mathrm{~m} / \mathrm{s})$ に達している。

$\mathrm{Al}$ 母材に引張応力を負荷し， $\mathrm{UV}_{\mathrm{Ra}}$ と $\mathrm{UV}_{\mathrm{Rn}}$ を測定した 結果をFig. 8(a)に示す。引張の場合，Uずみが約 1\%まで はUずみの增加に比例して両音速ともほぼ同じ值で低下 し，約 1\%Uずみで約0.8〜 1\% $(24 \sim 30 \mathrm{~m} / \mathrm{s})$ の低下と なっている。その後 UV $\mathrm{Ra}_{\mathrm{R}}$ はさらに低下し、Uずみが約 $4 \%$ を超えると急激に増加している。 $\mathrm{UV}_{\mathrm{Rn}}$ はUずみが $2 \%$ 超えると急激に增加し，約 $3 \%$ 以上で $0 \%$ ひずみ時の音速 を超之ている。一方，压縮応力を負荷したときの結果を Fig. 8 (b)に示す。圧縮の場合, Uずみの増加とともに音速は 增加しているが, Ti と同様 $\mathrm{UV}_{\mathrm{Rn}}$ の方が $\mathrm{UV}_{\mathrm{Ra}}$ に比較して 増加は大きい. 約 $0.1 \%$ ひずみずは $\mathrm{UV}_{\mathrm{Ra}}$ および $\mathrm{UV}_{\mathrm{Rn}}$ と も増加は少ないが, その後両音速は急激に增加し， $5 \%$ U ずみにおいて $\mathrm{UV}_{\mathrm{Ra}}$ は約 $5.4 \%(165 \mathrm{~m} / \mathrm{s}), \mathrm{UV}_{\mathrm{Rn}}$ は約 $7.7 \%$ $(230 \mathrm{~m} / \mathrm{s})$ 増加している.

\section{$3.2 \mathrm{Al}$ 単結晶の音速測定結果}

単結唱 $\mathrm{Al}$ を用いて UV $\mathrm{R}$ を測定した結果をFig. 9 に示 す。困は横軸に試験片角度を示し，図中に結晶方位を既述 している。縦軸には測定した音速 $\mathrm{UV}_{\mathrm{R}}$ から $\mathrm{AV}_{\mathrm{R}}(3040 \mathrm{~m} /$

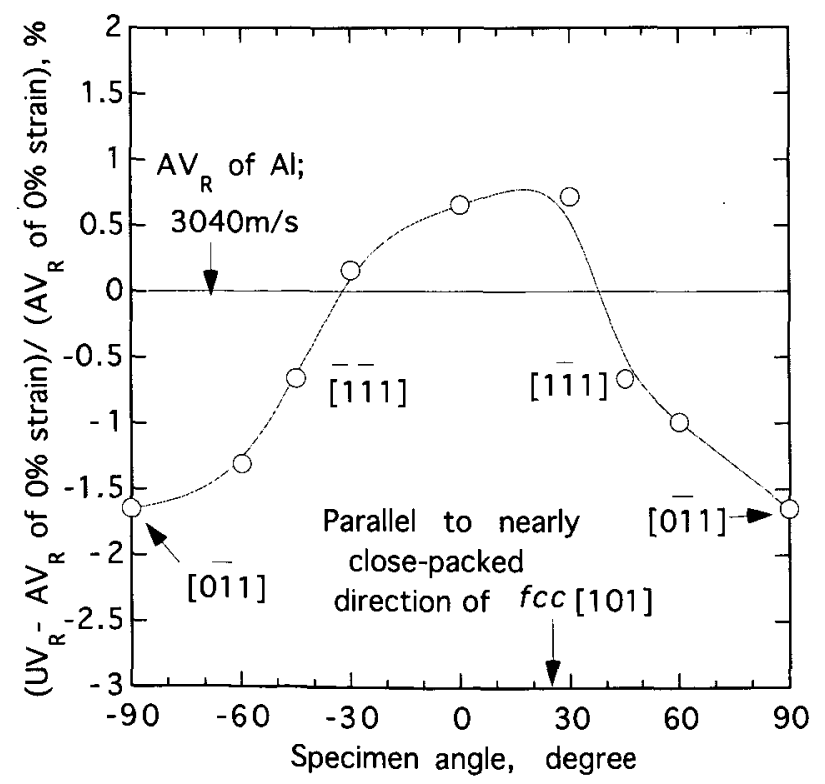

Fig. 9 Result of crystal direction versus $U V_{R}$ of single crystal pure Al. s）を引いた值を $\mathrm{AV}_{\mathrm{R}}$ で除し，その值を百分率で表示して いる，音速は最も低い [011] 万向の約 $2990 \mathrm{~m} / \mathrm{s}(-1.6 \%)$ 加ら, 最毛高い [101] に近い方向の約 $3060 \mathrm{~m} / \mathrm{s}(+0.7 \%)$ まで変化している。つまり，fcc 構造の最密方向である ［101］に平行に近い位置の音速が一番大きく，それに直角 方向の音速は低いことが分かる.

\section{$3.3 \mathrm{Ti} / \mathrm{Al}$ 摩擦圧接継手圧接面を横切る音速分布}

$\mathrm{AW}$ 継手の軸心, $1 / 2 \mathrm{R}$ 部および外周部において, 圧接面 をはさむ $4 \mathrm{~mm} の$ 範囲の $A V_{\mathrm{R}}$ の変化を Fig. 10 (a)に示子. 再母材とも音速分布は比較的バラツキが大きい．圧接面に 隣接する $\mathrm{Al}$ 側で音速は軸心部で最高約 $20 \%(600 \mathrm{~m} / \mathrm{s})$ 上 昇しているが，これを除くと $\mathrm{Ti}$ および $\mathrm{Al}$ 側ともー3〜+ $4 \%(-90 \sim+120 \mathrm{~m} / \mathrm{s})$ の範囲で変動している.また， Ti 側では，外周部の $\mathrm{AV}_{\mathrm{R}}$ が $1 / 2 \mathrm{R}$ 部㧍よび軸心部に比較し て若干高い值を示しているが，压接面に隣接する位置の $\mathrm{AV}_{\mathrm{R}}$ の上昇はほとんど見られない。 $573 \mathrm{~K}$ およじ873 K 継 手のそれらを Fig. 10(b)およU゙(c)にそれぞれ示す. $573 \mathrm{~K}$ 継 手においては, Ti および Al 母材とも AW 継手に比較して 音速のバラツキは減少し，圧接面に隣接する $\mathrm{Al}$ 側の音速 の増加もほとんど認められない. $873 \mathrm{~K}$ 縦手においては, 雨 母材ともに音速のバラッキはさらに小さいなり，位置によ る大きな差異も認妨られい。 また，压接面に隣接する位 置においても音速の急激な上昇は見られない。

$\mathrm{AW}$ 継手の軸心部, $1 / 2 \mathrm{R}$ および外周部において, 軸方向 に伝播する音速（UV $V_{\mathrm{Ra}}$ ) の測定結果を Fig. 11 (a)に示す。 Ti 側では音速分布は比較的バラツキがあるものの，圧接面 近傍に抢ける急激な変化は認められない。一方， $\mathrm{Al}$ 側の $\mathrm{UV}_{\mathrm{Ra}}$ のバラツキは比較的小さい.しかし, 半径方向各位置 において母材原質部から圧接面に问かうにつれて UV Ra 低下して扔り，圧接面から $0.25 \mathrm{~mm}$ の位置で約ー3〜 - $5 \%$ $(-90 \sim-150 \mathrm{~m} / \mathrm{s})$ になっている. しかし，圧接面にさら に近づいた位置では $\mathrm{UV}_{\mathrm{Ra}}$ は急激に增加し，その值は約十 9 9 +22\%(-280〜-670 m/s) に達している.

$\mathrm{AW}$ 継手の各位置の半径方向に伝播する音速 $\left(\mathrm{UV}_{\mathrm{Rr}}\right)$ を Fig. 11 (b)に示す. 再母材とも音速のバラッキは比較的大き いものの，圧接面近傍に抢ける急激な音速の増加は認如ら れない. $\mathrm{Ti}$ 側の $U V_{\mathrm{Rr}}$ は原質部上り高く, 約 $0 \sim+5 \%(0$ $\sim+150 \mathrm{~m} / \mathrm{s})$ の範国で変化している.一方, $\mathrm{Al}$ 側の $\mathrm{UV}_{\mathrm{Rr}}$ はどの位置においても母材原質部より低い值を示し，圧接 面に向かうにつれて UV $V_{R r}$ は若干低下している.

\section{$3.4 \mathrm{Ti} / \mathrm{Al}$ 摩擦圧接継手境界を横切る硬さ分布}

$\mathrm{AW}$ 継手の軸心, $1 / 2 \mathrm{R}$ 部㧈よび外周部において, 圧接面 をはさむ $4 \mathrm{~mm}$ の範团の硬さ分布を Fig. 12 (a)に示し， 573 K および873 K 継手のそれらをFig. 12 (b)および(c)にそれ ぞれ示す. Ti 原質部の硬さは HV 約 $150, \mathrm{Al}$ のそれは HV 約35であった， AW 継手において，圧接面から $1 \mathrm{~mm}$ 離れ た Ti 側の硬さは，原質部のそれより高い $\mathrm{HV}$ 約155〜190 

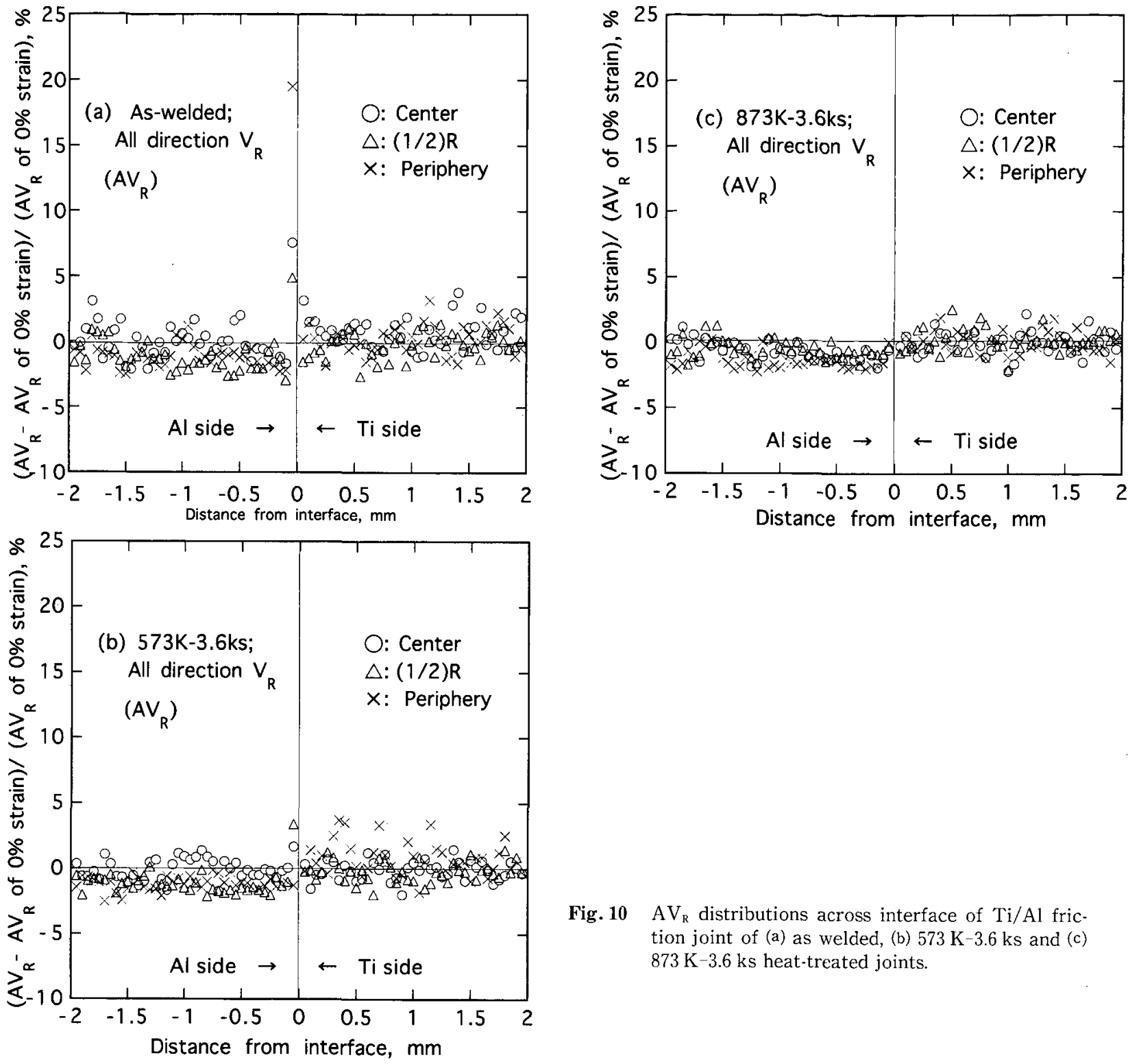

Fig. $10 A V_{R}$ distributions across interface of $\mathrm{Ti} / \mathrm{Al}$ fric tion joint of (a) as welded, (b) $573 \mathrm{~K}-3.6 \mathrm{ks}$ and (c) $873 \mathrm{~K}-3.6 \mathrm{ks}$ heat-treated joints.
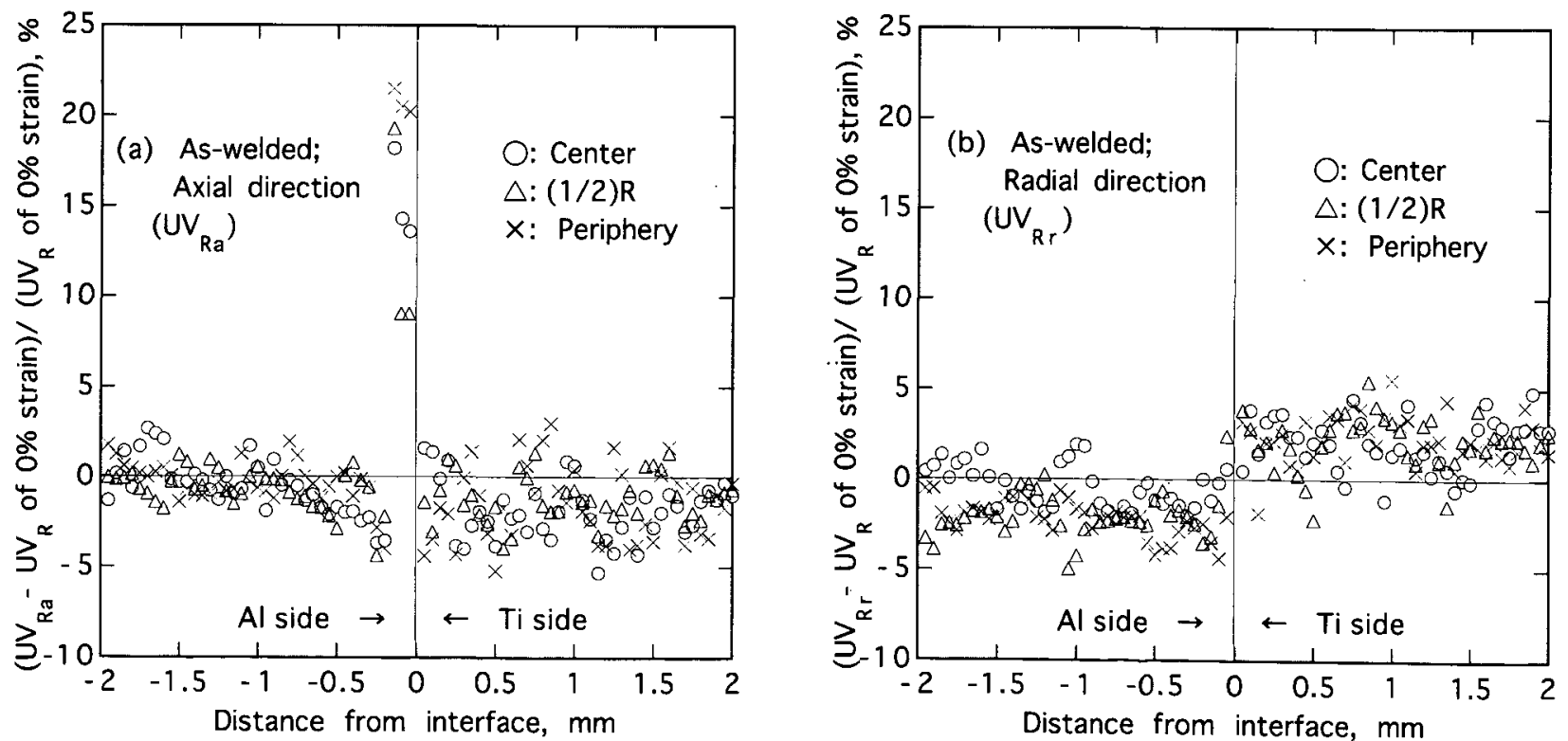

Fig. $11 U V_{R}$ distributions across interface of as-welded $\mathrm{Ti} / \mathrm{Al}$ joint of (a) axial and (b) radial direction. 

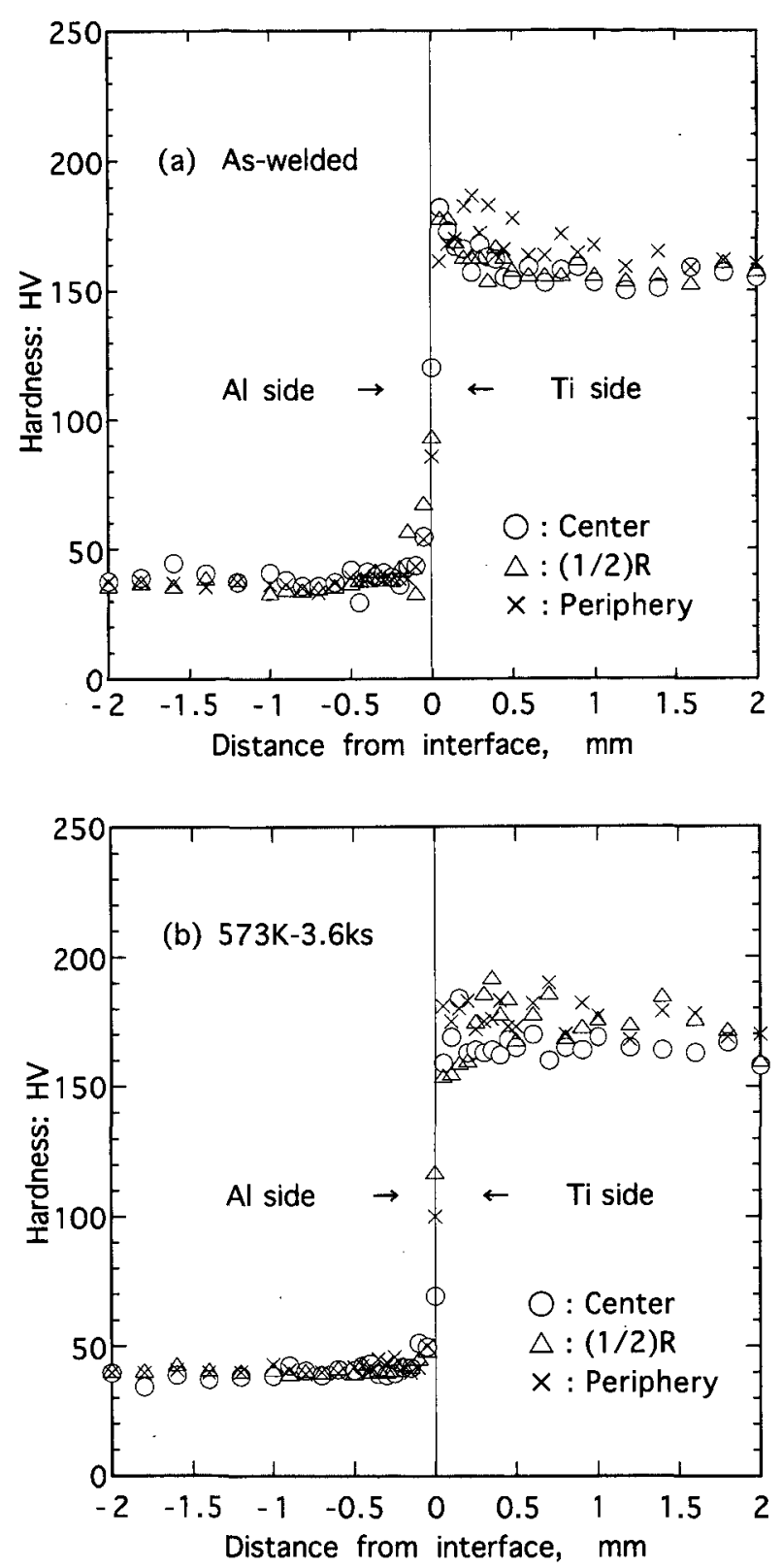

を示している。一方, 圧接面に隣接する $\mathrm{Al}$ 側でも $\mathrm{HV}$ 約 30 高い HV70 前後まで上昇している。 $573 \mathrm{~K}$ 継手の Ti 側の 硬さは母材原質部に近く, $\mathrm{Al}$ 側では圧接面から $0.15 \mathrm{~mm}$ までの範围で HV 約10 15の上昇が認められるものの，そ の值は $\mathrm{AW}$ 継手の硬さの上昇よりも小さい. $873 \mathrm{~K}$ 継手の 圧接面では Ti および $\mathrm{Al}$ 母材とも硬さのバラツキは小さ くなっている.しかし，圧接面に隣接する $\mathrm{Al}$ 側約 $0.2 \mathrm{~mm}$ の範囲の硬さは HV20 程度の上昇が認められる.

\section{4. 考察}

\section{$4.1 \mathrm{Ti}, \mathrm{Al}$ 母材並びに $\mathrm{Al}$ 単結晶の音速}

横波および表面波の理論音速は，それぞれ(4)および(5)式

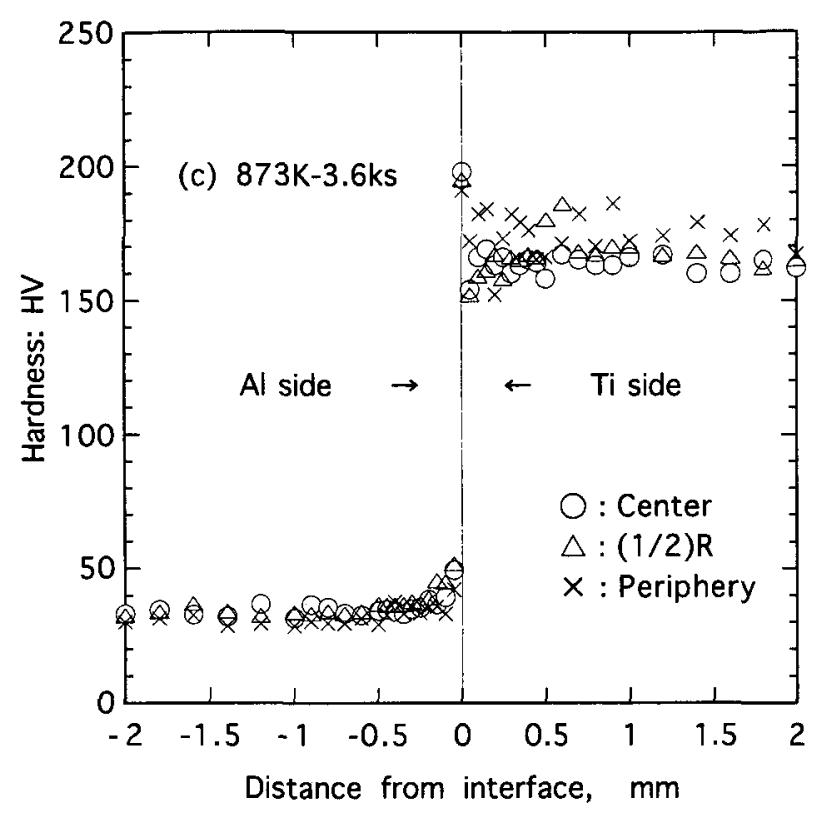

Fig. 12 Hardness distributions across $\mathrm{Ti} / \mathrm{Al}$ joint interface of (a) as welded, (b) $573 \mathrm{~K}-3.6 \mathrm{ks}$ and (c) $873 \mathrm{~K}$ $-3.6 \mathrm{ks}$ heat-treated joints.
で求まる26,27).

横波の音速 $=\{\mathrm{E} /[\rho \times 2 \times(1+\nu)]\}^{1 / 2}$

表面波の音速 $=0.9 \times$ 横波の音速

ここに, $\mathrm{E}$ : 縦弾性係数, $\rho$ : 密度, レ:ポアソン比である. 今, $\mathrm{Ti} の \mathrm{E}: 106 \mathrm{GPa}, \rho: 4.51 \times 10^{3} \mathrm{~kg} / \mathrm{m}^{3}, \nu: 0.34^{29)}$, Alのそれらを $70 \mathrm{GPa}, 2.70 \times 10^{3} \mathrm{~kg} / \mathrm{m}^{3}, 0.33$ とすると ${ }^{30)}$, $\mathrm{Ti}$ の横波は約 $2990 \mathrm{~m} / \mathrm{s}$, 表面波は約 $2690 \mathrm{~m} / \mathrm{s}, \mathrm{Al}$ はそれぞ れ約 $3150 \mathrm{~m} / \mathrm{s}$ および約 $2840 \mathrm{~m} / \mathrm{s}$ となる.本実験では負荷 ひずみ $0 \%$ の時の意速，つまり母材の音速は Ti が $2970 \mathrm{~m} /$ $\mathrm{s}, \mathrm{Al}$ が $3040 \mathrm{~m} / \mathrm{s}$ であり，いずれも横波に近い音速が得ら れている。

材料に応力（ひずみ）が負荷された場合の音速の変化に ついては詳細な報告はなされていないものの，一般に引張 応力/ひずみが増加するにつれて音速は低下するといわれ 
ている ${ }^{25)}$. とくに，音響学的に均質等方である高分子材料の ポリメチルメタアクリレート (PMMA)においては，引張 応力が存在する領域では応力の増加に伴い音速は低下し， 圧縮応力が存在する領域では音速が上昇すると報告されて いる15)。また， $\mathrm{Fe}-3 \% \mathrm{Si}$ を用いた音速测定では，引張ひ ずみが負荷された場合，音速が低下した例が示されてい $ろ^{31}$. 音速の変化には, 材料の弾性率や組織の変化等いくつ かの因子が影響を及ぼすが，本実験の範囲では，ひずみの 増加に伴う音速の変化を, 弾性域と思われる負荷ひずみ約 $0.2 \%$ での範囲で比較すると, $\mathrm{AV}_{\mathrm{R}}$ の場合, 音速は $\mathrm{Al}$ 母 材の引張においては低下し，圧緶においては変化は少な かった. また， Al 母材と同様に，Ti 母材の引張においても $\mathrm{AV}_{\mathrm{R}}$ は低下し，圧縮においては変化は少なかった，UV は，Al 母材の引張においては低下し，圧縮においては上昇 したが,一方, Ti 母材の引張および圧縮においては上昇し た.また, $\mathrm{UV}_{\mathrm{Ra}}$ と $\mathrm{UV}_{\mathrm{Rn}}$ の差は, Tiの方が $\mathrm{Al}$ に比較して 大きかったつまり, $\mathrm{Al}$ は圧縮応力を負荷した $A V_{\mathrm{R}}$ を除い ては，負荷ひずみと音速との間に一部相関がみられた。し

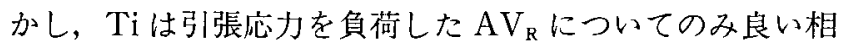
関が見られ，弾性領域における $\mathrm{AV}_{\mathrm{R}}$ の変化は $\mathrm{Al}$ よりも大 きかった. とくに圧縮応力を負荷した場合，Al と異なる傾 向を示している． UV $\mathrm{Ra}_{\mathrm{Ra}}$ と $\mathrm{UV}_{\mathrm{Rn}}$ の差が両材料で異なる理 由は，Tiの音響異方性が $\mathrm{Al}$ に比較して大きいことに起因 し，これは結晶構造に原因しているものと推定される。す なわち，方向性を有する音速の場合には，両材料で結果が 異なっており，今後各種材料におけるデー夕収集が必要に なるものと思われる。

ところで, SAM を用いて音速を求める場合, 測定値は材 料の音響インピーダンス $\left(Z_{\mathrm{A}}\right)$ に依存し，また $Z_{\mathrm{A}}$ は[音速 $\times$ 密度]で求められる ${ }^{11}$. $\mathrm{Ti}$ および $\mathrm{Al}$, 比較材として鋼, 本 奏験でカップラントとして使用した水の $Z_{\mathrm{A}}$ を求めると， Ti : $13.4 \times 10^{6}, \mathrm{Al}: 8.2 \times 10^{6}$, 鋼: $39.5 \times 10^{6}$, 水: $1.5 \times$ $\left.10^{6}\left[\mathrm{~kg} / \mathrm{m}^{2} \cdot \mathrm{s}\right)\right]$ となる.つまり, 鋼の $Z_{\mathrm{A}}$ は Ti 拈よび $\mathrm{Al}$ に比較してかなり大きく，さらに水と鋼の間では大きな差 がある。つまり，音響レンズから出る超音波のうち，表面 波として材料中に入る割合が少なくなり，鋼と水のような 組合せにおいては比較的測定が難しくなるものと考えられ る ${ }^{11}$. とくに, ステンレス鋼は, 内部微視組織による散乱が 大きいため, 音速測定は難しいとされている. 過去の研究 では，部分安定化 $\mathrm{ZrO}_{2}$ セラミックス (PSZ) と $\mathrm{Ni}$ との接 合界面の音速が測定されているが25), この場合, PSZの $Z_{\mathrm{A}}$ は約 $19.5 \times 10^{6}, \mathrm{Ni} の そ れ は 26.3 \times 10^{6}\left[\mathrm{~kg} /\left(\mathrm{m}^{2} \cdot \mathrm{s}\right)\right]$ とな $\eta$, 両材料の $Z_{\mathrm{A}}$ の差は比較的小さい.

純 $\mathrm{Al}$ の結唱方位と音速については， $f c c$ の最密方向に近 い方向で最も高い音速が得られた。一般的には結晶方位と 音速との間には方向によってピーク值が認められるともい われている。しかし，音速は種々の因子によって影響を受 けるため, 数 $100 \mu \mathrm{m}$ 程度の $\mathrm{Al}, \mathrm{Ni}, \mathrm{Cu} の$ 音速の理論值を 弾性定数加解き, 測定結果と併也て結晶方位と音速の関

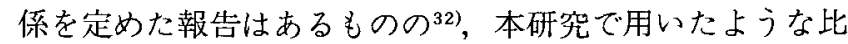
較的大きい単結晶の音速を測定した例は少ない。本研究の 範囲では, 結晶方位の変化による音速の変化は最大約 $2.3 \%$ $(70 \mathrm{~m} / \mathrm{s})$ 程度あったが，実際の材料はほとんどが多結晶体 であるので, 方向性の影響は小さくなるものと推定される.

\section{$4.2 \mathrm{Ti} / \mathrm{Al}$ 継手の音速と硬さ分布}

軸心部， $1 / 2 \mathrm{R}$ 部および外周部の各位置の圧接面に隣接 する位置において，Al 側の方が $\mathrm{Ti}$ 側より音速の変化は大 きいことから, $\mathrm{Al}$ 側には大きな塑性ひずみが生じているこ
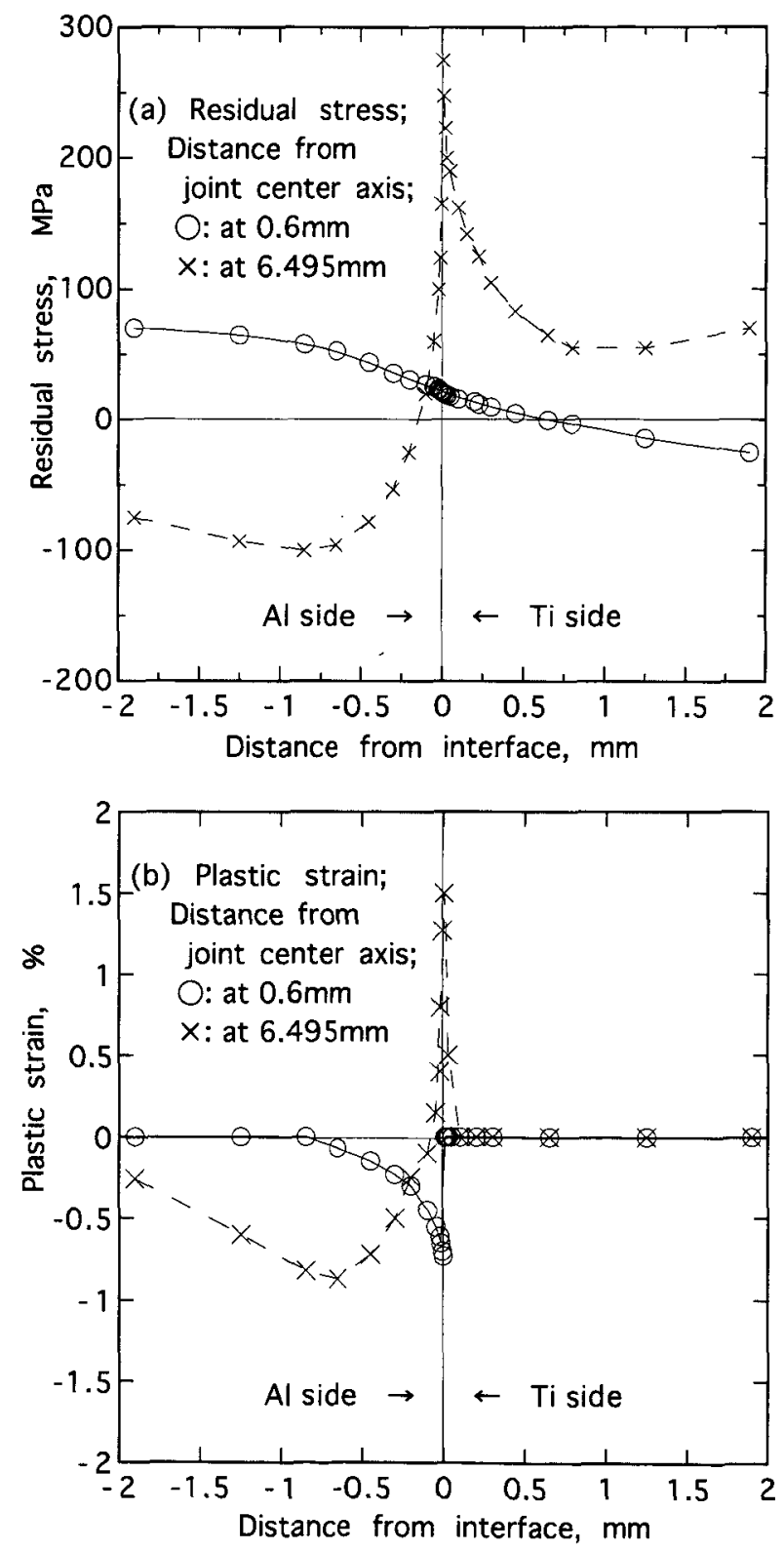

Fig. 13 Distributions of calculated axial direction residual stress and plastic strain at distance of 0.6 and 6.495 $\mathrm{mm}$ from axial center line of as welded pure $\mathrm{Ti} /$ pure $\mathrm{Al}$ joint of (a) residual stress and (b) plastic $\operatorname{strain}^{30)}$. 
とが推定される。異材継手の強度には接合界面に垂直な方 向の残留応力・Uずみが大きな影響を及ぼすので，以下こ の方向について考察を行なう.Fig. 13 (a)は，有限要素法を 用いて熱弾塑性解析を行ない, Ti/ $\mathrm{Al}$ 摩擦压接 $\mathrm{AW}$ 縦手の 圧接面を横切る位置での軸方向の残留応力を著者らが求奻 た結果の一部である゙3). Fig. 13 (b)は同じく塑性ひずみを計 算した結果の一部である.2.2で述べたように本研究で用い た試料では，残留応力については計算値よりも低い值にな るものと考えられるが，軸心部においては压接面をはさん で Ti 側および $\mathrm{A} 1$ 側とも引張応力になっている，外周部で は圧接面をはさんで高い引張応力になり， $\mathrm{A}$ 側では圧接面 から約 $0.2 \mathrm{~mm}$ 離れたところから圧縮に，Ti側は引張応力 になっている。一方軸心部の塑性Uずみは，圧接面に隣接 する $\mathrm{Al}$ 側で約 $0.7 \%$ の圧縮の塑性ひずみが生じており， $0.7 \mathrm{~mm}$ 離れるとほとんど 0 になっている. Ti 側の塑性U ずみは汪とんどない．外周部では雨材料とも压接面をはさ んだ約 $0.15 \mathrm{~mm} の$ 範囲において約 $1.5 \%$ 高い引張の塑性 Uずみが生じている.しかし，Al 側のひずみは急激に低下 L, 約 $0.1 \mathrm{~mm}$ の位置で圧縮ひずみになっている.つまり, 外周部および軸心部とも，圧接面に隣接する $\mathrm{Al}$ 側のこれ らの大きい塑性ひずみが音速を大きく増加させ，母材原質 部よりも硬さが上昇した原因になったものと推定される. ところで, 筆者らは $\mathrm{Ti} / \mathrm{Ti}$ 摩擦压接継手境界部を横切る音 速，硬さ，ひずみ分布について検討を行い，すでに報告し ている ${ }^{34)}$ ここの中で, 同様材の圧接継手においては, 圧接面 近傍に塑性ひずみはほとんど発生しないので，音速および 硬さの上昇が小さいことを明らかにした。このことを考え 合わせると, 異種材料の摩擦圧接継手の圧接面近傍では, 上述したように大きな塑性ひずみが発生していることが裹 付けられる.

$573 \mathrm{~K}$ 継手においては音速の変動が少なく，また圧接面 に隣接する両母材の音速の急激な変化も認められない。こ れは, $\mathrm{Al} の$ 再結晶温度に近い $573 \mathrm{~K}$ で熱処理を施したた め, 主として $\mathrm{Al}$ 側のUずみの一部が解放され, それにつれ て Ti側のひずみも若干解放されたためと考えられる。そ の結果, 圧接面の硬さは HV180程度であり上昇はほとんど ない.

$873 \mathrm{~K}$ 継手においては音速のバラツキがさらに小さく なっている.これは Tiの再結晶温度に近い873 K で熱処理 を施したため，Uずみが大きく解放されたためと考えられ る.軸心部の圧接面から $0.05 \mathrm{~mm}$ 離れた $\mathrm{Ti}$ 側の音速は約 $4 \%(120 \mathrm{~m} / \mathrm{s})$ 低下している。圧接面から $0.05 \mathrm{~mm}$ 離れた $\mathrm{Al}$ 側においては軸心部, $\mathrm{I} / 2 \mathrm{R}$ および外周部で音速が約 6 〜 12\% (180 m/s - 370 m/s) 高い值が得られている.これ は $\mathrm{Al} の$ 融点に近い温度で熱処理を施したため, 生じてい た塑性ひずみはほぼ解放されたものの，その後の冷却時に 両材料の線膨張係数と弾性率の差に起因して応力・Uずみ が再び生じたためと思われる。また，圧接面における硬さ は再びHV200付近まで上昇していることもこれに起因し
ているものと考えられる.

本実験では，音速，硬さとUずみの間には，一部にある 程度の相関が認められた。しかし，SAMによる音速の測定 には，試料表面の粗さの増加とともに音速が低下するが， ダイヤモンドペーストを用いたバフ研磨を行うことで測定 の高い再現性を示すと言われている(7).つまり，試料表面の 性状が音速測定に影響を及ぼすことから，異材継手の境界 部の音速と応力・ひずみとの関係を定量的に求めることは， まだまだ難しい課題があるものと考えられる。過去の音速 の理論計算と実験に関する研究においても, 表面処理方法, つまり表面性状の既述が少ない場合が多い. 最近, SAMに よる表面波の高精密測定法が提案されており ${ }^{35)}$, 今後, 表面 状態より高い精度での測定が必要であるものと思われる。

\section{5. 結}

本研究では, 純 $\mathrm{Ti} /$ 純 $\mathrm{Al}$ 異種材料摩擦圧接継手境界部の 応力・Uずみを，超音波顕微鏡で測定した表面波音速から 推定するための基礎的検討を行った，その中で，工業用純 チタン（Ti）と純アルミニウム（Al）の音速に及ぼす引張 および圧縮応力 (Uずみ) 上影響を求め, さらに純 $\mathrm{Al}$ 単結 晶の結晶方位と音速との関係を求めた。ざらに，接合した まま $(\mathrm{AW}) ， 573 \mathrm{~K}-3.6 \mathrm{ks}$ および873 K-3.6 ks の後熱処理 を施した $\mathrm{Ti} / \mathrm{A} 1$ 摩摖圧接継手境界部の音速分布並びに硬 さ測定を行い, 残留応力・Uずみとの関係について考察を 行った。 以下に得られた知見を要約する.

（1）弾性領域では Ti 招よび $\mathrm{Al}$ 母材とも，引張負荷Uず みの増加とともに音速は比較的良い相関を有しながら低下 したが，圧縮負荷ではUずみ量約 $3 \%$ \%で音速変化はほと んど現れなかった，Ti 母材では，引張㧍よび圧縮方向お上 びこれに垂直な方向の音速は，Uずみの增加によっていず れも上昇した。一方，A1 母材では引張方向および垂直方向 ともひずみの增加とともに音速は低下し，圧縮の場合はい ずれの方も上昇した。

（2）純 $\mathrm{Al}$ 単結晶の音速は, [011]に近い方向で最も遅 $く, f c c$ 構造の最密方向の [101]に近い方向が最も速かっ た.

(3) AW 継手の全方位の音速分布は比較的バラッキが 多く認められた，圧接面に隣接する $\mathrm{Al}$ 側で約 $10 \%$ の音速 の上昇が見られたものの，Ti側では上昇はほとんど認めら れなかった，継手に後熱処理を施すことにより，音速分布 のバラッキは低下し，圧接面に隣接する位置での音速の上 昇は現れなかった。

(4) $\mathrm{AW}$ 継手の軸方向及び半径方向に伝わる音速分布 は比較的バラツキが多かった，さらに，圧接面に隣接する $\mathrm{Al}$ 側において軸方向の音速は約 $20 \%$ 上昇したが、これは接 合時に発生した塑性ひずみに起因しているものと考えられ た.

(5) $\mathrm{AW}$ 継手の圧接面に隣接する領域では Ti および 
Al 母材とも, 接合時の塑性Uずみに起因して硬さが上昇し た.しかし，後熱好理によりこの硬さの上昇はほとんどな くなった。

\section{謝 辞}

本研究の一部は, 文部省の科学研究費補助金 （C08650083）の交付を受けて実施されたものである。研究 に対しましては，北見工業大学機械システム工学科教授小 林道明博士，並びに東北大学大学院工学研究科材料プロセ 又工学専攻助教授三原毅博士に有益なご助言を頂きまし た。また，奏験遂行におきましては，北見工業大学機械シ ステム工学科技官遠国秀昭, 大森誠一, 阿部清, 山田忠永 の各氏にご尽力を頂きました，各位にお礼申し上げます。

\section{参 考 文 献}

1) A. Fuji, T.H. North and K. Ameyama: Improving tensile strength and bend ductility of titanium/AISI 304L stainless steel friction welds, 8-3 (1992), 219-235.

2）富士，飴山，他：工業用純 $\mathrm{Ti} /$ 純 $\mathrm{Al}$ の摩擦圧接継手の特性にお よぼす後熱処理の影響，本誌諭文集，12-1（1994)，101-107。

3) A. Fuji, T.H. North, M. Kimura and K. Ameyama : Effect of friction welding conditions of characteristics of pure titanium/A5083 aluminum alloy joint, Material Science Research International, 1-3 (1995), 188-197.

4) A. Fuji, K. Ameyama and T.H. North : Influence of silicon in aluminium on the mechanical properties of titanium/aluminium friction joint, J. of Materials Science, 30 (1995), 5185 -5191 .

5) A. Fuji, K. Ameyama and T.H. North: Improved mechanical properties in dissimilar Ti/AISI 304L joints, Journal of Materials Science, 31 (1996), 819-827.

6) Y.C. Kim, A. Fuji and T.H. North : Residual stress and plastic strain in AISI 304L stainless steel/titanium friction welds, Materials Science and Technology, 11-4 (1995), 383-388.

7）金，朴，富士，伊藤： $\mathrm{Cu} / \mathrm{Al}$ 摩擦圧接継手の残留応力・塑性ひず み, 日本機械学会 M\&M '98材料力学部門講演会, 1998-11.

8）戸田：材料中の音速の測定，本誌，62-6（1993)，21-26.

9）仙波：超音波顕微鏡の工業計測への忘用，バウンダリー，4 月 (1986), 17-20.

10）石川：超音波顕微鏡とその芯用, 熱処理, 26-6(1986)，435-442.

11）山中：超音波顕微鏡とその材料評価への応用，材料， 35-399 (1986), 1341-1351.

12）石川：超音波顕微鏡による加工変質層の厚さの計測, 精密工学 会誌, 55-8 (1989), 16-19.
13）石川, 神田, 他：超音波顕微鏡によるセラミックス加工表面の評 価，非破壊検查，昭和61年秋季大会論文 (1986)，630-631.

14）木土, 瀬尾, 他：超音波顕微鏡による弾性表面波速度測定結果に 及ぼす残留芯力及じ表面粗さの影響, 日本機械学会講演論文集, 974-2 (1997), 137-138.

15）島田，渡辺，小幡，三原；LINE-FOCUS-BEAM を用いた超音 波顕微鏡に上る㐫力測定 (均一応力場の場合), 非破壞検查, 36-8 (1987), 540-545.

16）轎, 他：超音波に上る塑性変形域の画像検出法の検討，日本機㖑 学会論文雄 (A 編)，60-570（1994），204-210.

17）三原，佐藤，他：線収束型超音波顕微鏡によるジルコニア/ステ ンレス絴采傾斜機能材料の弾性定数の測定, 日本金属学会誌, 59-3 (1995), 325-330.

18）久保, 古村, 他：超音波顕微鏡によるガスタービン動翼コーティ ング少化の非破壊評価，日本機械学会第73期全国大会講演論文 集, 931-71 (1995)，334-335.

19）加藤，西尾，山口，他：SAM 及び TEMによるアルミニウム合 金の溶接金属中に形成される羽毛状晶の椮討，本誌論文集， 14-4 (1996), 698-702.

20）石川：超音波顕微鏡による材料評価，金属，67-10（1997）, 823-830.

21) 西村, 他：高分子材料の微小領域の性能評価に関する研究(第 1 報），日本機械学会論文集（A 編），63-606（1997），135-139.

22）同（第 2 報），63-611 (1997)，115-120.

23）菅沼，来川他：超音波顕微鏡によるセラミックス中の圧子損傷 の観察と評価，愛知県工業技術センター報告，29 (1993)，1-8.

24）小林, 莱津, 他：音弾性効果と組織音響効果の周波数依存性, 日 本機械学会論文集 (A 編)，65-636 (1999)，1747-1755.

25）成田，超音波顕微鏡による接合界面近傍の残留応力測定の可能 性，日本金属学会会報，29-11（1990），918-923。

26）石川, 成田, 他：超音波顕微鏡によるセラミックス・金属接合部 の評価 (来発表)

27）実吉，他・編集：超音波技術便覧，日刊工業新聞社，(1966), 1324-1329.

28）中村，吉久，深井：方かる音響学，日新出版，(1985).

29）高橋編集：非鉄金属材料選択のポイント，日本規格協会 (1992), 237.

30）社軽金属協会：アルミニウムハンドブック(第 5 版) (1994), 25.

31）石川, 神田, 片倉, 他：超音波顕微鏡による結晶粒内の歪観察, 非破壊検查, Vol. 33, No. 9, P. 730-731.

32) M.G. Somekh, G.A.D. Briggs and C. Ilett: The effect of elastic anisotropy on contrast in the scanning acoustic microscope, Philosophical Magazine A, 49, 2 (1984), 179-204.

33）金, 朴, 冨士, 他：チタンとアルミニウムの摩擦压接で生じる残 留応力・塑性Uずみ，高温学会誌，21-5 (1995)，202-208.

34）冨士，金，他：工業用純 Ti 摩擦圧接継手境界部の硬さ特性と超 音波伝搬特性に関寸る研究，高温学会誌，1-6(1995)，320-326.

35）岡出，河合，他：超音波顕微鏡による表面波の高精密度測定，日 本機械学会第73期全国大会講演論文集, 931-71(1995)，539-540. 